\title{
EXPLORING GENDER AND CASTE INTERSECTIONALITY AMONG MUSLIMS: A SOCIOLOGICAL STUDY
}

\author{
RABIYA YASEEN BAZAZ \\ Department of Sociology, Aligarh Muslim University \\ Aligarh, Pin 202002, India \\ E-mail address: rabiyabazaz@gmail.com \\ ORCID: https://orcid.org/0000-0002-2954-4728 \\ MOHAMMAD AKRAM \\ Department of Sociology, Aligarh Muslim University \\ Aligarh, Pin 202002, India \\ E-mail address: akram_soc@yahoo.co.in \\ ORCID: https://orcid.org/0000-0002-4874-6149
}

\begin{abstract}
Aim. Caste studies conducted among Muslims in India generally focus on establishing the existence of a caste system among Muslims, but they seldom talk about different types of oppression and inequalities faced by Muslim women. This empirical study explores how gender and caste identities and their mutual intersectionality impact education, occupation, income choices and the actual attainments of Muslim women.

Methods. This study is part of a larger study conducted among Muslims of Kashmir in India. Primary data was collected from 704 eligible respondents (392 male, 312 female) using mixed methods. Three layers of 'caste-like' and 'caste' groups existing in the research area are identified and gender situation within these groups are comparatively examined.

Results and conclusion. Each of the 'caste-like' and 'caste' groups has patriarchal caste capital. Higher professions within the government and private services are largely acquired by upper caste male Muslims. There is a preponderance of lower caste male Muslims in low income self-employment, but lower caste Muslim females seldom find employment in family-based businesses and are compelled to take low-paid private jobs. Not all women face inequality in the same way: while upper caste Muslim women often witness benevolent restriction of choices, lower caste women are the most excluded section of the society. They face double discrimination due to patriarchy and interwoven caste positions, which severely impacts their educational and employment choices.
\end{abstract}

Originality. This is an original research paper based on the findings of the doctoral work conducted by the first author and supervised by the second author.

Key words: gender, caste, education, employment, patriarchy 


\section{INTRODUCTION}

$\square$ ender-based discrimination and inequality exist both in the developed and in the developing societies, and many studies have shown that women continue to face oppression in private and public spheres (Gupta, 2019; Oakley, 1974; Smith, 2013) and that they have been subject to patriarchal norms which impact their educational, occupational and income choices (Sudarshan, 2016; Wolkowitz, 2006). Gender is a social construction where members of each sex, through gender socialisation, learn the socially expected behaviours and roles (Oakley, 1974). Gender socialisation affects the self-concepts of women and men and creates gender identity which forms the base of gender based stratification system. Chand (1994) defines gender as an ideology of male chauvinism which sees women as secondary and inferior to men and which is preoccupied with the domestication of women and with establishing control over their sexuality. In stratified societies, gender often combines with the existing oppressive stratification systems and creates a complex situation of oppression that needs to be better understood empirically. Without taking into account the complexity of the system of stratification and discrimination, it is difficult to approach and understand women oppressive structures.

Influenced by the Marxian school of thought, socialist feminism finds the origins of women's oppression in the system of capitalism and argues that women constitute a cheap supply of labour; they are exploited by capitalism in a similar way that the working class is exploited. Further, it argues that women's unpaid work at home sustains not just men's productive work in the economy but also the structures of capitalism (Smith, 2013). Holmes (2007) argues that radical feminism interprets patriarchy as the primary cause of women's oppression. However, these approaches generalised the problems of women, who of course do not constitute a homogenous category. In this regard, postmodernists focus on the diversity and multiple discourses. Central to this perspective is the argument that there is no universal experience associated with being a woman.

Wolkowitz (2006) argues that different categories of women face different kinds and levels of oppression. Their particular social location in a radically stratified society accrues different privileges and disadvantages to women. Gender inequality does not exist in vacuum; it often interacts with the existing oppressive system. The empirical work conducted by Acker (2006) shows that in a stratified society gender intersect with race, class, religion, nationality, ethnicity, and all these factors impacted women differently. Despite this diversity within gender, the diversities of discrimination are not taken into account in several academic works. Anderson and Tylor (2008) argue that most of the feminist movement focuses on middle-class women and ignore the issues and problems of 'women of colour'. Myrdal and King (1972) found parallels between caste and race and argued that racial problems are somewhat similar to caste issues in India. 
India is largely stratified not only on the basis of class but also of caste. Many studies confirm that caste is an important form of stratification in India which continues to influence the distribution process. The development trajectories followed by India is often criticised for being non-inclusive in nature. The benefit of high growth largely remains confined to those with particular caste identities (Hirway, 2015). Acharya (2018) observers: "caste in India is instrumental in deciding who owns land, who supplies labour, who marries whom, the occupation one can engage in, the food one can eat and with whom, and who gets educated and develops a certain kind of skill, and so on" (Acharya, 2018, p. 108). Bougle (1958) highlighted three essential features of caste system in India: caste hereditary, specialisation, hierarchy and repulsion. Bailey (1957) referred caste as hereditary occupational groups and focused on how it plays a role in taking up positions of advantage in the new economic scenario. Many studies confirmed the fact that caste system is not only confined to Hindus but caste practices also prevails among Muslims (Ahmed, 1978; Bazaz, 2020; Chand, 1994; Mondal, 2003) especially among those who are historically converted Muslims. The empirical studies conducted by Bazaz and Akram (2020) on Kashmir observed that educational, employment and income-related achievements of most of the respondents show the prevalence of social hierarchy existing at the level of some caste-like and caste groups.

In India, Muslims constitute more than 12 percent of the total population (Census, 2011). Muslim population in India represents the mixture of groups drawn from the indigenous converters and foreign ancestors (Ahmad, 1962). Muslims are the followers of Islam, which theoretically advocates for an egalitarian society and prohibits any distinction which divides people into low or high and pure or impure (Ahmad, 1962). The existence of caste system among the Muslims in India has been an object of analysis for a long time and has raised enough debates among the scholars. Mines (1978) argues that Muslims are different from Hindus in ethos and social stratification and not comparable in any respect to the Hindu caste system while other scholars assert that many Hindu caste practices are prevalent among the Muslims of India (Ahmed, 1978; Bhattacharya, 1978; Mondal, 2003). Several studies divide Muslims into two groups as Ashraf and Ajlaf based on their birth and descent (Mondal, 2003; Zainuddin, 2003). In Kashmir, certain studies on caste have divided caste into five categories, where they place Sayyids at the top followed by Sheikh, Mughals, Pathans, and Taifadarans (Lawrence, 1891; Sinha, 2003). The debate regarding the prevalence of caste among the Muslims often arises because caste is conventionally seen in continuity with Varna and the four-fold birth-based hierarchy prevailing within it (Ahmed, 1978). The same study of Ahmed argues that "Muslim community is not a homogenous entity; they are differentiated into various groups and sub-groups along ethnic, social, and cultural lines and are organised in a stratified social order" (p. 1459). Pathania and Tierney (2018) close the debate by arguing that in modern society, caste continues to shape inequality, though not in the same traditional way, but in more hidden and different forms where particular caste uses its 'caste capital' to influence the distribution process. 
Many sociological studies explored the interconnection of caste, class and gender: for example, the study conducted by Velaskar (2016) focuses on the intersectionality of gender and class, but the work is largely theoretical in nature. Another important work in this direction is the study conducted by Gupta (2019) where the author has explored the impact of caste on the academic achievement of men and women. But the author has largely focused on educational institutions and ignored social and cultural practices prevailing at the family level, which impacts the choices of members of different castes. Sen (1999) argues that education, occupation and income are some of the important indicators of inclusive growth which are positively correlated to each other and determines socio-economic status of an individual. The study conducted by Velaskar (1990), Chand (1994) and Sudarshan (2016) argue that women continue to be marginalised, and that most of the policies designed to tackle gender inequality failed to yield appropriate results because the complexity of the oppression system is not properly understood and taken into account. Jamil (2018) says that mainstream feminist movement in India has side-lined the issues and problems faced by Muslim and Dalit women.

The review of the existing literature suggests that there is a dearth of academic work conducted within sociological framework which aims at exploring gender and caste intersectionality and their impact on educational, occupational and income choices and actual attainments. Further, most of the caste studies conducted among Muslims in India focus on the existence of caste system and its problems, and little attention has been given to the oppression and inequality faced by the women of different caste groups among Muslims and the impact of such inequality on their socio-economic attainments and choices. There is absolute lack of such studies conducted in Jammu and Kashmir (a region largely populated with Muslims) and this study intends to fill this gap. With this background this study will explore gender and caste intersectionality with particular focus on how gender and caste identity impacts education, occupation and income choices and actual attainments among Muslims in Kashmir region of India.

\section{METHODOLOGY}

This study was conducted in Nalabal, Alamgari Bazar and Baghi Ali Mardan Khan areas of district city Srinagar of the state (now union territory) of Jammu and Kashmir, India. The universe of this study is all those people who are in labour force including housewives who are looking for some paid employment but excluding students who are enrolled in some educational institutions or those who are below 15 and above 65 years old. This study covered all 245 households from the above mentioned adjoining areas consisting of 704 eligible respondents available in the research area. A semi-structured interview schedule was used for collecting data from all these respondents. Our schedule contained forty questions related to demographic, socio-cultural and economic background of the respondents and other specific questions related to the research. One of the 
authors met the respondents and collected information in a local language. Specific quantitative data was analysed by using SPSS. Some specific cases showing unique attributes were also selected for detailed interviews, but the names of the respondents were changed in this paper. Many case studies which have helped in developing insights and applying triangulation are included in this paper.

\section{FINDINGS}

\section{Caste and caste-like groups}

This empirical study found 53 different family titles/surnames at household level prevailing within the research area, namely: Saiyid, Rizvi, Siddique, Qadri, Fazile, Hamdani, Khan, Beg, Khawaja, Sheikh, Qureshi, Bulbul, Poosh, Gani, Mir, Shah, Rather, Bazaz, Malik, Qazi, Baba, Hakak, Raja, Bhat, Rangrez, Zargar, Alai, Parray, Naqati, Misgarh, Kharadi, Munshi, Lone, Kozghar, Naqaash, Wani, Bisati, Want, Kumar, Gogeery, Shora, Najar, Joo, Chalak, Tanki, Sofi, Dar, Nayee, Ganae, Kalo, Nago, Dhobee and Darzee. Members of these groups identified themselves as distinct groups that showed association with specific historical, cultural or occupational specificity. These titles/surnames are often referred to by local people as zaat or biradari which means 'caste' or 'caste-like group'. At the time of the analysis of the empirical data, it was observed that education, employment and income-related achievements of most of the respondents show the prevalence of some invisible social hierarchy existing at the level of these groups. There could be many other such groups, but we have included only those which are found in the research area.

We are considering these groups identified through surnames (family names) as 'caste' and 'caste-like groups' because of the specific socio-cultural and historical context of construction of these surnames and their conventional association with specific occupations and networking of social and cultural capital. In this study, we have categorised these 53 castes and caste-like groups into three groups, namely; Group-I, Group-II, and Group-III. Group-I and II are 'caste-like groups' and Group-III is 'caste group'. The brief description of these three 'caste' and 'caste-like groups' are presented here:

Group-I: Groups who claim to belong to the families of Prophet Muhammad (PBUH) and other dynasties of Arabian origin. It includes the following family titles: Saiyid, Rizwi, Siddique, Qadri, Fazile, Hamdani, which we consider as caste-like groups. This group constitutes eight percent of the total respondents. They are identified as caste-like groups because they do not strictly follow the criterion of having a traditional occupation.

Group-II: Groups whose surnames reflect the foreign origin of the communities and who have migrated to India at different intervals of time. It includes the following family titles: Khan, Beigh, Khawaja, which we consider as caste-like groups. This group constitutes 16 percent of the total respondents. They are also identified as caste-like groups because they no longer strictly follow the criterion of having a traditional occupation. 
Group-III: Occupational groups/surnames, some of which closely resemble the Hindu counterparts. These are most likely converted indigenous people or are closely associated with them. The group includes the following family titles: Shiekh, Qureshi, Bulbul, Poosh, Gani, Mir, Shah, Rather, Bazaz, Malik, Qazi, Hakak, Raja, Bhat, Rangrez, Zargar, Alai, Parray, Naqati, Misgarh, Kharadi, Munshi, Lone, Kozghar, Naqaash, Wani, Bisati, Want, Googery, Tanki, Darze, Shor, Najar, Sofi, Dar, Nayi, Ganae, Kolu, Nago, Dhobee, which we consider as castes. This group constitutes 76 percent of the total respondents. They are identified as caste groups because they exhibit all features of caste including the association with traditional occupation.

\section{Educational attainment and choices of caste groups}

In order to explore educational attainment of various caste groups, we have categorized education into five categories: (i) illiterate; (ii) primary to senior secondary or up-to senior secondary; (iii) technical education; (iv) professional education; and (v) graduate and above (excluding professional and technical courses) or GA(EPTC) (please see Table 1).

Table 1.

Gender and caste wise educational attainment

\begin{tabular}{|c|c|c|c|c|c|c|c|}
\hline \multicolumn{8}{|c|}{ Educational categories } \\
\hline Sex & $\begin{array}{l}\text { Caste } \\
\text { Groups }\end{array}$ & $\begin{array}{l}\text { Illiter- } \\
\text { ate }\end{array}$ & $\begin{array}{l}\text { Primary } \\
\text { to senior } \\
\text { second- } \\
\text { ary }\end{array}$ & $\begin{array}{l}\text { Tech- } \\
\text { nical } \\
\text { Educa- } \\
\text { tion }\end{array}$ & $\begin{array}{c}\text { Profes- } \\
\text { sional }\end{array}$ & $\begin{array}{l}\text { GA } \\
\text { (EPTC) }\end{array}$ & Total \\
\hline \multirow[t]{4}{*}{ Males } & Group-I & $0.0 \%$ & $10.7 \%$ & $3.6 \%$ & $25.0 \%$ & $60.7 \%$ & $100.0 \%$ \\
\hline & Group-II & $7.9 \%$ & $41.3 \%$ & $3.2 \%$ & $23.8 \%$ & $23.8 \%$ & $100 \%$ \\
\hline & Group-III & $14.3 \%$ & $49.2 \%$ & $2.0 \%$ & $9.0 \%$ & $25.6 \%$ & $100.0 \%$ \\
\hline & Total & $12.2 \%$ & $45.2 \%$ & $2.3 \%$ & $12.5 \%$ & $27.8 \%$ & $\begin{array}{l}100.0 \% \\
N=392\end{array}$ \\
\hline \multirow{4}{*}{ Females } & Group-I & $0.0 \%$ & $20.0 \%$ & $4.0 \%$ & $24.0 \%$ & $52.0 \%$ & $100.0 \%$ \\
\hline & Group-II & $3.8 \%$ & $37.7 \%$ & $0.0 \%$ & $20.8 \%$ & $37.7 \%$ & $100.0 \%$ \\
\hline & Group-III & $6.8 \%$ & $40.6 \%$ & $0.9 \%$ & $15.4 \%$ & $36.3 \%$ & $100.0 \%$ \\
\hline & Total & $5.8 \%$ & $38.5 \%$ & $1.0 \%$ & $17.0 \%$ & $37.8 \%$ & $\begin{array}{l}100.0 \% \\
N=312\end{array}$ \\
\hline \multirow[t]{4}{*}{ Total } & Group-I & $0.0 \%$ & $15.1 \%$ & $3.8 \%$ & $24.5 \%$ & $56.6 \%$ & $100.0 \%$ \\
\hline & Group-II & $6.0 \%$ & $39.7 \%$ & $1.7 \%$ & $22.4 \%$ & $30.2 \%$ & $100.0 \%$ \\
\hline & Group-III & $11.0 \%$ & $45.4 \%$ & $1.5 \%$ & $11.8 \%$ & $30.3 \%$ & $100.0 \%$ \\
\hline & Total & $9.4 \%$ & $42.2 \%$ & $1.7 \%$ & $14.5 \%$ & $32.2 \%$ & $\begin{array}{l}100.0 \% \\
N=704\end{array}$ \\
\hline
\end{tabular}

Source: own research

It is important to mention here that in this study, higher education includes professional education, technical education, and GA(EPTC). Each educational category is further sub-divided on the basis of various courses (Table 1a). 
Table 1a.

Detailed educational qualification of respondents

\begin{tabular}{|c|c|c|c|c|c|c|c|c|}
\hline \multicolumn{9}{|c|}{ Sub-divisions of educational category of up to senior secondary } \\
\hline Sex & $\begin{array}{l}\text { Caste } \\
\text { Groups }\end{array}$ & Primary & Middle & $\begin{array}{l}\text { Matric- } \\
\text { ulation }\end{array}$ & $\begin{array}{c}\text { Senior } \\
\text { Secondary }\end{array}$ & \multicolumn{2}{|c|}{$\begin{array}{l}\text { Any Certificate } \\
\text { Course }\end{array}$} & Total \\
\hline \multirow[b]{4}{*}{$\frac{\mathscr{d}}{\frac{\pi}{\pi}}$} & Group-I & $0.0 \%$ & $33.3 \%$ & $33.3 \%$ & $33.3 \%$ & \multicolumn{2}{|c|}{$0.0 \%$} & $100.0 \%$ \\
\hline & Group-II & $0.0 \%$ & $34.6 \%$ & $42.3 \%$ & $23.1 \%$ & \multicolumn{2}{|c|}{$0.0 \%$} & $100.0 \%$ \\
\hline & \begin{tabular}{|l} 
Group- \\
III
\end{tabular} & $5.4 \%$ & $25.7 \%$ & $39.9 \%$ & $28.4 \%$ & \multicolumn{2}{|c|}{$0.7 \%$} & $100.0 \%$ \\
\hline & Total & $4.5 \%$ & $27.1 \%$ & $40.1 \%$ & $27.7 \%$ & \multicolumn{2}{|c|}{$0.6 \%$} & $\begin{array}{l}100.0 \% \\
(\mathrm{~N}=177)\end{array}$ \\
\hline \multirow{4}{*}{ 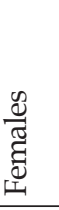 } & Group-I & $0.0 \%$ & $20.0 \%$ & $60.0 \%$ & $20.0 \%$ & \multicolumn{2}{|c|}{$0.0 \%$} & $100.0 \%$ \\
\hline & Group-II & $0.0 \%$ & $25.0 \%$ & $40.0 \%$ & $35.0 \%$ & \multicolumn{2}{|c|}{$0.0 \%$} & $100.0 \%$ \\
\hline & Group-III & $5.3 \%$ & $14.7 \%$ & $47.4 \%$ & $32.6 \%$ & \multicolumn{2}{|c|}{$0.0 \%$} & $100.0 \%$ \\
\hline & Total & $4.2 \%$ & $16.7 \%$ & $46.7 \%$ & $32.5 \%$ & \multicolumn{2}{|c|}{$0.0 \%$} & $\begin{array}{l}100.0 \% \\
(\mathrm{~N}=120)\end{array}$ \\
\hline \multicolumn{9}{|c|}{ Courses within professional education } \\
\hline Sex & $\begin{array}{l}\text { Caste } \\
\text { Groups }\end{array}$ & $\begin{array}{c}\text { Engi- } \\
\text { neering }\end{array}$ & Medical & Law & $\begin{array}{c}\text { Manage- } \\
\text { ment } \\
\text { Social } \\
\text { Work }\end{array}$ & $\begin{array}{l}\text { Journal- } \\
\text { ism }\end{array}$ & $\begin{array}{l}\text { B.Ed./ } \\
\text { M.Ed. }\end{array}$ & Total \\
\hline \multirow[b]{4}{*}{$\frac{\mathscr{\mathscr { d }}}{\sum^{\frac{\pi}{z}}}$} & Group-I & $57.1 \%$ & $0.0 \%$ & $0.0 \%$ & $42.9 \%$ & $0.0 \%$ & $0.0 \%$ & $100.0 \%$ \\
\hline & Group-II & $46.7 \%$ & $33.3 \%$ & $0.0 \%$ & $20.0 \%$ & $0.0 \%$ & $0.0 \%$ & $100.0 \%$ \\
\hline & Group-III & $33.3 \%$ & $22.2 \%$ & $3.7 \%$ & $33.3 \%$ & $3.7 \%$ & $3.7 \%$ & $100.0 \%$ \\
\hline & Total & $40.8 \%$ & $22.4 \%$ & $2.0 \%$ & $30.6 \%$ & $2.0 \%$ & $2.0 \%$ & $\begin{array}{l}100.0 \% \\
(\mathrm{~N}=49)\end{array}$ \\
\hline \multirow{4}{*}{ 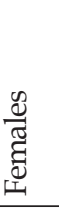 } & Group-I & $33.3 \%$ & $16.7 \%$ & $0.0 \%$ & $16.7 \%$ & $0.0 \%$ & $33.3 \%$ & $100.0 \%$ \\
\hline & Group-II & $9.1 \%$ & $9.1 \%$ & $0.0 \%$ & $36.4 \%$ & $0.0 \%$ & $45.5 \%$ & $100.0 \%$ \\
\hline & Group-III & $5.6 \%$ & $5.6 \%$ & $11.1 \%$ & $27.8 \%$ & $2.8 \%$ & $47.2 \%$ & $100.0 \%$ \\
\hline & Total & $9.4 \%$ & $7.5 \%$ & $7.5 \%$ & $28.3 \%$ & $1.9 \%$ & $45.3 \%$ & $\begin{array}{l}100.0 \% \\
(\mathrm{~N}=53)\end{array}$ \\
\hline \multicolumn{9}{|c|}{ Courses within technical education } \\
\hline Sex & \begin{tabular}{|l|} 
Caste \\
Group \\
\end{tabular} & Related & $\begin{array}{l}\text { to Engine } \\
\text { Computer }\end{array}$ & ring and & Related $\mathrm{t}$ & $\begin{array}{l}\text { Nursing } \\
\text { echnician }\end{array}$ & nd Lab & Total \\
\hline \multirow[b]{4}{*}{$\frac{\mathscr{D}}{\sum_{\Sigma}^{\frac{\pi}{\Sigma}}}$} & Group-I & & $100 \%$ & & & $0.0 \%$ & & $100.0 \%$ \\
\hline & Group-II & & $100 \%$ & & & $0.0 \%$ & & $100.0 \%$ \\
\hline & Group-III & & $66.7 \%$ & & & $33.3 \%$ & & $100.0 \%$ \\
\hline & Total & & $77.8 \%$ & & & $22.2 \%$ & & $\begin{array}{l}100.0 \% \\
(\mathrm{~N}=9)\end{array}$ \\
\hline \multirow{4}{*}{ 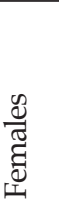 } & Group-I & & $0.0 \%$ & & & $100 \%$ & & $100.0 \%$ \\
\hline & Group-II & & $0.0 \%$ & & & $0.0 \%$ & & 0 \\
\hline & Group-III & & $50.0 \%$ & & & $50.0 \%$ & & $100.0 \%$ \\
\hline & Total & & $33.3 \%$ & & & $66.7 \%$ & & $\begin{array}{c}100.0 \% \\
(\mathrm{~N}=3)\end{array}$ \\
\hline
\end{tabular}




\begin{tabular}{|c|c|c|c|c|c|c|c|}
\hline \multicolumn{8}{|c|}{ Courses within GA (EPTC) } \\
\hline Sex & $\begin{array}{l}\text { Caste } \\
\text { Group }\end{array}$ & $\begin{array}{l}\text { Only } \\
\text { Gradu- } \\
\text { ate }\end{array}$ & M.A & M.SC & M.Com & $\begin{array}{l}\text { Ph.D./ } \\
\text { M.Phil. }\end{array}$ & Total \\
\hline \multirow[b]{4}{*}{$\frac{\mathscr{g}}{\pi}$} & Group-I & $41.2 \%$ & $29.4 \%$ & $11.8 \%$ & $11.8 \%$ & $5.9 \%$ & $100.0 \%$ \\
\hline & Group-II & $62.5 \%$ & $6.2 \%$ & $12.5 \%$ & $12.5 \%$ & $6.2 \%$ & $100.0 \%$ \\
\hline & \begin{tabular}{|l} 
Group-III \\
\end{tabular} & $69.2 \%$ & $7.7 \%$ & $9.0 \%$ & $11.5 \%$ & $2.6 \%$ & $100.0 \%$ \\
\hline & Total & $64.0 \%$ & $10.8 \%$ & $9.9 \%$ & $11.7 \%$ & $3.6 \%$ & $\begin{array}{c}100.0 \% \\
(\mathrm{~N}=111)\end{array}$ \\
\hline \multirow{4}{*}{ 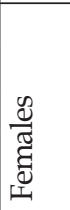 } & Group-I & $53.8 \%$ & $30.8 \%$ & $7.7 \%$ & $7.7 \%$ & $0.0 \%$ & $100.0 \%$ \\
\hline & Group-II & $50.0 \%$ & $20.0 \%$ & $15.0 \%$ & $15.0 \%$ & $0.0 \%$ & $100.0 \%$ \\
\hline & Group-III & $54.2 \%$ & $32.5 \%$ & $4.8 \%$ & $2.4 \%$ & $6.0 \%$ & $100.0 \%$ \\
\hline & Total & $53.4 \%$ & $30.2 \%$ & $6.9 \%$ & $5.2 \%$ & $4.3 \%$ & $\begin{array}{l}100.0 \% \\
(\mathrm{~N}=116)\end{array}$ \\
\hline
\end{tabular}

Source: own research

The caste wise educational attainment of respondents is presented in Table 1. In this study, it is observed that literacy rate among male and female is 87.7 percent and 94.2 percent respectively. Further, among all male respondents $(\mathrm{N}=392), 12.2$ percent are illiterate, 45.2 percent have educational qualifications varying between primary to senior secondary, 2.3 percent have technical education, 12.5 percent have professional education, and 27.8 percent are GA(EPTC). The educational profile of females $(\mathrm{N}=312)$, reveal that 5.8 percent are illiterate, 38.5 percent have educational qualifications varying between primary to senior secondary, one percent have technical education, 17 percent have professional education and 37.8 percent are GA(EPTC).

Educational attainment of Group-III women in comparison to women of other caste groups is much lower. We observed that of the total Group-I females, none of the respondents are illiterate and almost 80 percent possess some higher qualifications, out of which almost 30 percent have some technical and professional qualification, and above 50 percent are GA(EPTC) (Table 1). Among Group-I women who have some professional qualification, almost 50 percent have completed their professional degree from engineering and medical and 33.3 percent have done B.Ed./M.Ed. (Table 1a). This shows better educational choices available to women from Group-I and their good educational attainment. Answering to a question related to who takes decisions related educational and occupational choices of women in the family, Nida Sayyid who is presently working as a doctor and belongs to Sayyid family, said:

Most of my career choices are taken by my father. My father is religious and highly educated person. He believed that it is our responsibility to acquire both religious and worldly knowledge. My father told me that if I choose general studies (non-professional) I may have to excel a lot and the entire process would be quite time taking which can defer my marriage. It is because of his suggestions and guidance that I did MBBS. My father told me even if I do 
not get a job after doing my MBBS, I will earn a reputed degree and valuable knowledge (source: own fieldwork data).

Nida Sayyid claims that they are the progeny of Prophet Muhammad (PBUH) and believes that it is a birth right and duty to acquire knowledge. Nida Sayyid's case shows that obtaining higher education in a professionally very reputed course was her family's choice and it paved her path of joining a very reputed profession. She acknowledges that she got benefitted by a strong support of cultural and social capital prevailing at family level. The traditional association of Sayyids with knowledge appears well in Nida Sayyid's case. Sinha (2003) says that Sayyids subgroups in Kashmir are Saadat-e-Hamadaniya (Peerzada), Mantaqi, Baihaqi, Rizvi, Mosavi, Shirazi, Andrabi and Bukhari. Hence, Sayyids, as a caste-like group belong to upper strata and the women coming from this caste-like group get the benefits of cultural and social capital getting converted as caste capital.

The educational profile of Group-III woman reveals that of the total Group-III females, 6.8 percent are illiterate, 40.6 percent have some lower qualifications varying between primary to senior secondary and 52.6 percent have some higher qualifications, out of which only 0.9 percent have any technical education, 15.4 percent have done professional courses and 36.3 percent are GA(EPTC) (Table 1). Further, it is observed that of the total Group-III females who are GA(EPTC) almost 70 percent are 'only graduates'. There is under-achievement of Group-III females in technical and scientific subjects. This biased subject choice is important because courses like engineering and medical are considered very prestigious and employment-oriented (Table 1a). These women tend to concentrate in those disciplines, usually identified as feminine commanding weak rewards in terms of wage, authority and social prestige. Thus, the educational profile of Group-III women is quite distressing and possibly, both home and school processes are at work in the realisation of this stereotyped result and our case studies substantiate the same.

After completing secondary education, Sakina Tendaa (Tendaa is Group-III caste) left her studies. When asked about the reasons of this decision, she said:

I hail from a family where none from previous generations were educated and I think only educated parents understand the value and worth of education. It was my dream to attain some higher education. It was not financial constraints which barred me and my sister from acquiring education as my brothers are receiving their education without any hindrance. My family, especially my father, never supported our education. Being girls we were supposed to look after our home and other domestic activities which somewhere created obstacles for us to acquire education. My father used to tell us that we will not get anything by acquiring education and we should concentrate on learning cooking and cleaning works. (source: own fieldwork data)

These lines depict gender stereotyping, sexism, and patriarchy prevailing there among the Group-III castes.

From the narratives of Nida Sayyid and Sakina Tendaa, we observe that women of different caste face gender discrimination differently which impacts 
their educational attainment and choices differently. Gender stereotyping and some forms of patriarchy exist in both the cases of Sakina Tendaa and Nida Sayyid. However, gender stereotyping and patriarchy is more rigidly practiced among lower castes where we observe that education of males is prioritised over female's education as visible in Sakina Tendaa's family. Women's primary roles and responsibilities, in lower castes, are regarded as being wives, daughters-in-law and mothers, and this suggests not only prevalence of lesser cultural capital but also narrow choices and opportunities for women. Traditionally, upper caste possesses caste capital which provides them with particular cultural capital, social capital, and symbolic capital supporting their academic choices and attainment.

The prevalence of lower cultural capital among lower castes, especially Group-III castes, is visible from the fact that across all caste groups, the educational profile of Group-III males are remarkably lower and of the total Group-III males: almost 14 percent are illiterate, almost 50 percent have some lower qualifications varying between primary to senior secondary and 36 percent (approximately) have some higher qualification. Thus, almost 64 percent of total Group-III males have some lower or no qualification (Table-1). Nazir Najar left education after doing matriculation. Najar is a Group-III caste and in Kashmiri language Najar means 'carpenter' (Dabla, 2009; 2012). Occupation of carpentry is often looked down in Kashmir and in other parts of India carpentry is given the status of Other Backward Class (OBC) who get affirmative support from governments in education and government jobs. On asking Mr. Nazir Najar why he left education after doing matriculation he said:

I was not interested in studying as mere educational qualification would not give me any government job. For government job we need some contacts with people who are working in that sector. So rather than continuing my studies and wasting time and money I started working as a driver. (source: own fieldwork data)

Mr. Aafaq Dar is a matriculate and is working as skilled artist in papier mache ('paper moulding'), which is their traditional occupation. Dar was the surname of a Hindu caste of Kashmir who was Kshatriyas before their conversion to Islam, historically. Dar was a popular surname among the land cultivators and farmers in rural Kashmir. However, this surname is then used by the fishermen community of Kashmir and is also known as Gaad Haenz (Sinha, 2003) and is one of the low and Group-III castes of Kashmir. On asking Mr. Dar why he left education, he said: "from the very beginning, I was not interested in government job so I discontinued my studies after doing $10^{\text {th }}$ and joined my father's occupation." It is observed that most of the respondents visualise formal education, especially higher education, only as a means of acquiring qualifications and subsequently 'good job' (i.e., government job) in Kashmir. This confined role of education has put limits on its other important functions where it is no longer seen as an enhancer of choices and capabilities. It clearly shows prevalence of poor cultural and social capital and consequently poor caste capital among them. 


\section{EMPLOYMENT ATTAINMENT AND CHOICES OF CASTE GROUPS}

In this study, we have devised following five broad employment categories: (i) government service; (ii) private service; (iii) self-employment; (iv) daily wage worker; and (v) unemployed (please see Table 2). These employment categories are further sub-divided into various occupational positions (please see Table 2a). One can note from Table 2 that the proportion of males in government services is higher than females within their corresponding caste strata. This clearly shows the underrepresentation of women in most prestigious government services and the poor occupational attainment of women. Further, we observed that the overall presence of Group-I women in government services is much higher. It shows better positioning of Group-I (upper caste-like groups) women. Further, the proportion of Group-III males is lower in government service and their proportion is higher in self-employment. Self-employment is largely part of the unorganised sector. We observed that women of lower castes typically consider their employment as well as income status as distressing because there is little opportunity for them, even in self-employment. The employment profile of Group-III females reveals that only 13.2 percent of them work in government sector, 24.4 percent work in private sector, 6.0 percent are self-employed, almost 9.4 percent work as daily wage worker, and about 47 percent of them are unemployed. The corresponding percentage for Group-I females is 32.0 percent for government sector, 28.0 percent for private sector, zero percent for self-employment, zero percent for daily wage worker, and 40.0 percent are unemployed (Table 2).

Table 2.

Gender and caste wise employment attainment

\begin{tabular}{|l|l|c|c|c|c|c|c|}
\hline \multicolumn{7}{|c|}{ Educational categories } \\
\hline \multirow{3}{*}{ Sex } & $\begin{array}{l}\text { Caste } \\
\text { Groups }\end{array}$ & $\begin{array}{c}\text { Govern- } \\
\text { ment } \\
\text { Service }\end{array}$ & $\begin{array}{c}\text { Private } \\
\text { Service }\end{array}$ & $\begin{array}{c}\text { Self Em- } \\
\text { ployed }\end{array}$ & $\begin{array}{c}\text { Daily } \\
\text { Wage } \\
\text { Workers }\end{array}$ & $\begin{array}{c}\text { Unem- } \\
\text { ployed }\end{array}$ & Total \\
\cline { 2 - 8 } & Group-I & $53.6 \%$ & $21.4 \%$ & $17.9 \%$ & $0.0 \%$ & $7.1 \%$ & $100.0 \%$ \\
\cline { 2 - 9 } & Group-II & $31.7 \%$ & $25.4 \%$ & $33.3 \%$ & $7.9 \%$ & $1.6 \%$ & $100 \%$ \\
\cline { 2 - 9 } & Group-III & $22.6 \%$ & $21.9 \%$ & $40.2 \%$ & $12.0 \%$ & $3.3 \%$ & $100.0 \%$ \\
\cline { 2 - 9 } & Total & $26.3 \%$ & $22.4 \%$ & $37.5 \%$ & $10.5 \%$ & $3.3 \%$ & $100.0 \%$ \\
& Group-I & $32.0 \%$ & $28.0 \%$ & $0.0 \%$ & $0.0 \%$ & $40.0 \%$ & $100.0 \%$ \\
\cline { 2 - 8 } & Group-II & $18.9 \%$ & $20.8 \%$ & $5.7 \%$ & $1.9 \%$ & $52.8 \%$ & $100.0 \%$ \\
\cline { 2 - 8 } & Group-III & $13.2 \%$ & $24.4 \%$ & $6.0 \%$ & $9.4 \%$ & $47.0 \%$ & $100.0 \%$ \\
\cline { 2 - 8 } & Total & $15.7 \%$ & $24.0 \%$ & $5.4 \%$ & $7.4 \%$ & $47.4 \%$ & $100.0 \%$ \\
& & & & & & $\mathrm{~N}=312$ \\
\hline
\end{tabular}


Journal of Education Culture and Society No. 2_2021

\begin{tabular}{|l|l|c|c|c|c|c|c|}
\hline \multirow{3}{*}{ Total } & Group-I & $43.4 \%$ & $24.5 \%$ & $9.4 \%$ & $0.0 \%$ & $22.6 \%$ & $100.0 \%$ \\
\cline { 2 - 8 } & Group-II & $25.9 \%$ & $23.3 \%$ & $20.7 \%$ & $5.2 \%$ & $25.0 \%$ & $100.0 \%$ \\
\cline { 2 - 8 } & Group-III & $18.5 \%$ & $23.0 \%$ & $25.2 \%$ & $10.8 \%$ & $22.4 \%$ & $100.0 \%$ \\
\cline { 2 - 7 } & Total & $21.6 \%$ & $23.2 \%$ & $23.3 \%$ & $9.1 \%$ & $22.9 \%$ & $\begin{array}{l}100.0 \% \\
\mathrm{~N}=704\end{array}$ \\
\hline
\end{tabular}

Source: own research

Table 2a.

Detailed occupational position of respondents

\begin{tabular}{|c|c|c|c|c|c|c|c|}
\hline \multicolumn{8}{|c|}{ Government Positions } \\
\hline Sex & $\begin{array}{l}\text { Caste } \\
\text { Groups }\end{array}$ & \begin{tabular}{|c|} 
Officer/ \\
Professor/ \\
Lecturer/ \\
Doctor/ \\
Eng
\end{tabular} & $\begin{array}{c}\text { Clerical/ } \\
\text { Supervisor }\end{array}$ & $\begin{array}{c}\text { Con- } \\
\text { tractual }\end{array}$ & $\begin{array}{r}\text { Gove } \\
\text { Teache } \\
\text { Te }\end{array}$ & $\begin{array}{l}\text { nment } \\
\text { / Senior } \\
\text { hers }\end{array}$ & Total \\
\hline \multirow[b]{4}{*}{$\frac{\stackrel{\mathscr{d}}{\pi}}{\sum^{\pi}}$} & Group-I & $60.0 \%$ & $33.3 \%$ & $0.0 \%$ & \multicolumn{2}{|c|}{$6.7 \%$} & $100.0 \%$ \\
\hline & Group-II & $60.0 \%$ & $40.0 \%$ & $0.0 \%$ & \multicolumn{2}{|c|}{$0.0 \%$} & $100.0 \%$ \\
\hline & Group-III & $23.5 \%$ & $57.4 \%$ & $14.7 \%$ & \multicolumn{2}{|c|}{$4.4 \%$} & $100.0 \%$ \\
\hline & Total & $35.9 \%$ & $50.5 \%$ & $9.7 \%$ & \multicolumn{2}{|c|}{$3.9 \%$} & $\begin{array}{c}100.0 \% \\
(\mathrm{~N}=103)\end{array}$ \\
\hline \multirow{4}{*}{ 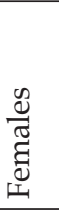 } & Group-I & $37.5 \%$ & $12.5 \%$ & $0.0 \%$ & \multicolumn{2}{|c|}{$50.0 \%$} & $100.0 \%$ \\
\hline & Group-II & $30.0 \%$ & $20.0 \%$ & $0.0 \%$ & \multicolumn{2}{|c|}{$50.0 \%$} & $100.0 \%$ \\
\hline & Group-III & $16.1 \%$ & $25.8 \%$ & $25.8 \%$ & \multicolumn{2}{|c|}{$32.3 \%$} & $100.0 \%$ \\
\hline & Total & $22.4 \%$ & $22.4 \%$ & $16.3 \%$ & \multicolumn{2}{|c|}{$38.8 \%$} & $\begin{array}{l}100.0 \% \\
(\mathrm{~N}=49)\end{array}$ \\
\hline \multicolumn{8}{|c|}{ Private Positions } \\
\hline Sex & $\begin{array}{l}\text { Caste } \\
\text { Groups }\end{array}$ & \begin{tabular}{|c} 
Officer/ \\
Professor/ \\
Lecturer/ \\
Eng/Prin- \\
cipal
\end{tabular} & $\begin{array}{c}\text { Clerical/ } \\
\text { Supervisor }\end{array}$ & $\begin{array}{l}\text { Fourth } \\
\text { Grade }\end{array}$ & $\begin{array}{l}\text { Sales } \\
\text { Men }\end{array}$ & Teacher & Total \\
\hline \multirow[b]{4}{*}{$\frac{\mathscr{Q}}{\frac{\pi}{\pi}}$} & Group-I & $50.0 \%$ & $50.0 \%$ & $0.0 \%$ & $0.0 \%$ & $0.0 \%$ & $100.0 \%$ \\
\hline & Group-II & $53.3 \%$ & $26.7 \%$ & $6.7 \%$ & $13.3 \%$ & $0.0 \%$ & $100.0 \%$ \\
\hline & Group-III & $19.4 \%$ & $47.8 \%$ & $13.4 \%$ & $13.4 \%$ & $6.4 \%$ & $100.0 \%$ \\
\hline & Total & $27.3 \%$ & $44.3 \%$ & $11.4 \%$ & $12.5 \%$ & $4.5 \%$ & $\begin{array}{l}100.0 \% \\
(\mathrm{~N}=88)\end{array}$ \\
\hline \multirow{4}{*}{ 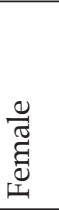 } & Group-I & $28.6 \%$ & $28.6 \%$ & $0.0 \%$ & $0.0 \%$ & $42.9 \%$ & $100.0 \%$ \\
\hline & Group-II & $9.1 \%$ & $27.3 \%$ & $18.2 \%$ & $0.0 \%$ & $45.5 \%$ & $100.0 \%$ \\
\hline & Group-III & $3.5 \%$ & $26.3 \%$ & $19.3 \%$ & $0.0 \%$ & $50.9 \%$ & $100.0 \%$ \\
\hline & Total & $6.7 \%$ & $26.7 \%$ & $17.3 \%$ & $0.0 \%$ & $49.3 \%$ & $\begin{array}{l}100.0 \% \\
(\mathrm{~N}=75) \\
\end{array}$ \\
\hline
\end{tabular}




\begin{tabular}{|c|c|c|c|c|c|c|c|}
\hline Sex & $\begin{array}{l}\text { Caste } \\
\text { Group }\end{array}$ & $\begin{array}{l}\text { Owner of } \\
\text { Factory/ } \\
\text { Manu- } \\
\text { facturing } \\
\text { Unit/ } \\
\text { Property } \\
\text { Dealer }\end{array}$ & $\begin{array}{c}\text { Owner of } \\
\text { Agriculture } \\
\text { Land/Farm } \\
\text { House/Gar- } \\
\text { den/ } \\
\text { Agro- } \\
\text { Product }\end{array}$ & \begin{tabular}{|c|c}
$\begin{array}{c}\text { Owner } \\
\text { of }\end{array}$ & Or \\
Dairy & $\mathrm{Sr}$ \\
Farm/ & $\mathrm{M}$ \\
Prod- & $\mathrm{fac}$ \\
uct & $\mathrm{i}$
\end{tabular} & $\begin{array}{l}\text { ner } \\
\text { f } \\
\text { tall } \\
\text { nu- } \\
\text { tur- } \\
\text { ng } \\
\text { its }\end{array}$ & $\begin{array}{l}\text { Owner } \\
\text { of } \\
\text { Shop/ } \\
\text { Hotel/ } \\
\text { Restau- } \\
\text { rant }\end{array}$ & Total \\
\hline \multirow[b]{4}{*}{$\frac{\stackrel{\infty}{d}}{\sum^{\frac{\pi}{2}}}$} & Group-I & $20.0 \%$ & $0.0 \%$ & $0.0 \%$ & $0 \%$ & $40.0 \%$ & $100.0 \%$ \\
\hline & Group-II & $9.1 \%$ & $4.5 \%$ & $0.0 \%$ & $6 \%$ & $22.7 \%$ & $100.0 \%$ \\
\hline & Group-III & $10.8 \%$ & $0.0 \%$ & $0.0 \%$ & $8 \%$ & $43.3 \%$ & $100.0 \%$ \\
\hline & Total & $10.9 \%$ & $0.7 \%$ & $0.0 \%$ & $3 \%$ & $40.1 \%$ & $\begin{array}{c}100.0 \% \\
(\mathrm{~N}=147)\end{array}$ \\
\hline \multirow{4}{*}{ 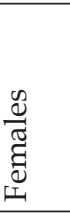 } & Group-I & $0.0 \%$ & $0.0 \%$ & $0.0 \%$ & $\%$ & $0.0 \%$ & $0.0 \%$ \\
\hline & Group-II & $0.0 \%$ & $0.0 \%$ & $0.0 \%$ & $7 \%$ & $33.3 \%$ & $100.0 \%$ \\
\hline & Group-III & $0.0 \%$ & $0.0 \%$ & $7.1 \%$ & $6 \%$ & $14.3 \%$ & $100.0 \%$ \\
\hline & Total & $0.0 \%$ & $0.0 \%$ & $5.9 \%$ & $5 \%$ & $17.6 \%$ & $\begin{array}{c}100.0 \% \\
(\mathrm{~N}=5)\end{array}$ \\
\hline \multicolumn{8}{|c|}{ Categories of Daily Wage Worker } \\
\hline Sex & Caste & Skilled & Semi-Skilled & \multicolumn{3}{|c|}{ Unskilled } & Total \\
\hline \multirow[b]{4}{*}{ 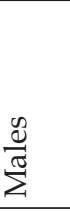 } & Group-I & $0.0 \%$ & $0.0 \%$ & \multicolumn{3}{|c|}{$0.0 \%$} & $0.0 \%$ \\
\hline & Group-II & $80.0 \%$ & $20.0 \%$ & \multicolumn{3}{|c|}{$0.0 \%$} & $100.0 \%$ \\
\hline & Group-III & $69.4 \%$ & $19.4 \%$ & \multicolumn{3}{|c|}{$11.1 \%$} & $100.0 \%$ \\
\hline & Total & $70.7 \%$ & $19.5 \%$ & \multicolumn{3}{|c|}{$9.8 \%$} & $\begin{array}{l}100.0 \% \\
(\mathrm{~N}=41)\end{array}$ \\
\hline \multirow{4}{*}{ 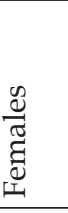 } & Group-I & $0.0 \%$ & $0.0 \%$ & \multicolumn{3}{|c|}{$0.0 \%$} & $0.0 \%$ \\
\hline & Group-II & $100.0 \%$ & $0.0 \%$ & \multicolumn{3}{|c|}{$0.0 \%$} & $100.0 \%$ \\
\hline & Group-III & $100.0 \%$ & $0.0 \%$ & \multicolumn{3}{|c|}{$0.0 \%$} & $100.0 \%$ \\
\hline & Total & $100.0 \%$ & $0.0 \%$ & \multicolumn{3}{|c|}{$0.0 \%$} & $\begin{array}{l}100.0 \% \\
(\mathrm{~N}=23)\end{array}$ \\
\hline \multicolumn{8}{|c|}{ Educational Unemployment } \\
\hline Sex & $\begin{array}{l}\text { Caste } \\
\text { Group }\end{array}$ & $\begin{array}{l}\text { Up to } \\
\text { Senior } \\
\text { Second- } \\
\text { ary } \\
\end{array}$ & $\begin{array}{l}\text { Technical } \\
\text { Education }\end{array}$ & $\begin{array}{c}\text { Profes- } \\
\text { sional Edu- } \\
\text { cation }\end{array}$ & \multicolumn{2}{|c|}{ GA(EPTC) } & Total \\
\hline \multirow[b]{4}{*}{$\frac{\stackrel{0}{\pi}}{\sum^{\frac{\pi}{2}}}$} & Group-I & $0.0 \%$ & $50.0 \%$ & $50.0 \%$ & & $0.0 \%$ & $100.0 \%$ \\
\hline & Group-II & $100.0 \%$ & $0.0 \%$ & $0.0 \%$ & & $0.0 \%$ & $100.0 \%$ \\
\hline & Group-III & $30.0 \%$ & $0.0 \%$ & $30.0 \%$ & & $0.0 \%$ & $100.0 \%$ \\
\hline & Total & $30.8 \%$ & $7.7 \%$ & $30.8 \%$ & & $0.8 \%$ & $\begin{array}{l}100.0 \% \\
(\mathrm{~N}=13)\end{array}$ \\
\hline \multirow{4}{*}{ 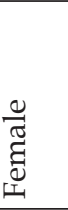 } & Group-I & $50.0 \%$ & $0.0 \%$ & $10.0 \%$ & & $0.0 \%$ & $100.0 \%$ \\
\hline & Group-II & $60.7 \%$ & $0.0 \%$ & $7.1 \%$ & & $2.1 \%$ & $100.0 \%$ \\
\hline & Group-III & $52.7 \%$ & $0.0 \%$ & $2.7 \%$ & & $4.5 \%$ & $100.0 \%$ \\
\hline & Total & $54.1 \%$ & $0.0 \%$ & $4.1 \%$ & & $1.9 \%$ & $\begin{array}{c}100.0 \% \\
(\mathrm{~N}=148)\end{array}$ \\
\hline
\end{tabular}

Source: own research 
Thus, it is visible that most of the Group-III women are either working in privates sector or are unemployed. Within private sector, 50 percent (approximately) of Group-III females work as private teachers which are low paid, further about 46 percent work as clerical or fourth grade employee and only 3.5 percent work as officers, professors, lecturers, engineers or principals. Similarly, of the total Group-III who are in government services, only 16 percent are the occupants of such positions as officers, professors, lecturers, engineers, doctors: almost 50 percent of these women occupy clerical or contractual positions in various government sectors, whereas 50 percent of Group-I females who are in government sector works as government teachers, and almost 37 percent are the occupants of such positions as officers, professors, lecturers, engineers or doctors (see Table 2a). "My father's friend knew several senior employees who were working in banks where I am presently working and they recommended me for the position," said Nazima Siddique (Siddique is a Group-I and caste-like group) who has done Bachelor of Commerce (B.Com., an undergraduate level qualification) and works in one of the leading banks of Kashmir.

The self-employment sector is very important for creating multiple employment opportunities in Kashmir. It is observed that Group-III males are self-employed in the study area. Though women comprise nearly half of the labour force, their presence is very limited in this sector, and the proportion of Group-III females is almost negligible. Saima belongs to Zargar caste which is one of the occupational and Group-III castes of Kashmir. In Kashmiri, the language of gold smiths is called Zargar. Saima said:

I was very interested in doing gold business but here in Kashmir doing business is very challenging for women. Women have to remain at shops and there is no fixed time of reaching home. In business, one has to travel and has to deal with opposite sex. Because of all these challenges, my father didn't allow me to join our family business. He told me that it is not good for women to do business. My brother who is looking after our family business also not allowed me to join him in business. (source: own fieldwork data)

Saima expressed her desire for doing business but her family restricted her career choice of doing business just because certain work environment is often deemed inappropriate for women. The fear of sexual harassment, gender stereo-typing and gender biasness, glass ceiling, the lack of confidence, etc. are some of the factors which stand in the way of Saima for doing business. Gruber reveals that sexual objectification often intersects with socio-cultural identities and ethnic identities where women who hail from lower strata of the society are often considered overly sexed, untamed, crude, and deserving of sexual exploitation and aggression (Gruber, 1998). The above case of Saima depicts that Saima's family fear that their daughter might become the victim of sexual harassment, eye teasing, stalking or other related problems. This shows how little choice Saima is having in her family business. This is an explicit example of constrained choices and gender discrimination within the level of her family and the larger caste group. 
We observe that none of the respondents from Group-I works as daily wage worker, and only small proportion of respondents from Group-II work as daily wage worker. It is largely Group-III respondents who work as daily wage worker (Table 2). It is observed that out of the daily wage workers, majority of respondents work as skilled labour (Table 2a) where most of them possess skills associated with such activities as: handicraft and handloom, papier-mache, tailoring, carpenter, copper-smith, plumber, painter, driver, barber and parlour artist etc. We observe that it is primarily Group-III males and females who are engaged in occupation associated with activities like carpenter, copper-smith, plumber, painter, driver, washer man, barber and parlour artist. These occupations were traditionally considered low in status and most of such occupations are associated with those castes and social categories which are now identified as Schedule Castes (SCs) and Other Backward Classes (OBCs) in the rest of India. Zubair Dar is a 23-year-old male and has done Bachelor of Commerce a few years back and is presently unemployed. His father is self-employed (a washer man popularly known as Dhobee in Kashmir) and manages to earn up to Rs. 15,000/- per month. On asking why he is unemployed, Dar responded:

I was working in one of the private company as receptionist. I left that job one year before because salary was very low (Rs. 3000/- per month) and office was far away from my home. I cannot join my father's work of washing clothes. I am unemployed and all my education is worthless. (source: own fieldwork data)

Dar's father is self-employed but his work resembles daily-wage work, and he has almost no space for his son to join him. If Dar joins his father's work, it would be 'disguised unemployment' because he will not make any productive return in the family income.

In this study, we observed that the unemployment rate for males and females is 3.3 percent and 47.4 percent respectively (Table 2). These figures show the extremely disadvantaged position of women in Kashmir. When these figures are compared with NSSO (2011-12), the corresponding male and female unemployment rates are 3.1 percent and 20.6 percent respectively. This definition of unemployment as given by NSSO has a limitation that it includes "women who are engaged in household work" in the category of "not in the labour force" and thus places them outside the category of unemployed or employed. Keeping in mind this limitation of the NSSO's methodology, this study has considered every individual who considers themselves available for work (even if engaged in domestic duties) as part of the labour force and maps the prevalence of unemployment in the research area. In terms of caste, we observed that of the total females from Group-I, Group-II and Group-III, proportion of females who are unemployed are 40.0 percent, 52.8 percent and 47.4 percent, respectively. The educational profile of unemployed females reveal that 54.1 percent have educational qualifications varying between primary to senior secondary, 4.1 percent have professional and technical training, and 
almost 41.9 percent are GA(EPTC) (Table 2a). The concentration of low caste Group-III women is high in the non-professional and non-technical courses, and the rate of unemployment is highest in courses which are non-professional and non-technical in nature, which leaves the women with almost no choice but either to join a low paid private job or remain unemployed or in a state of disguised unemployment. We observe that women's employment choices are influenced by various socio-economic and cultural constraints and not just availability of job or eligibility for the same. Rashida Rizwi (Rizwi is Group-I caste) has done Master of Science (M.Sc.) and Bachelor of Education (B.Ed.) and is unemployed; she said:

I am looking for some teaching position at government sector. In Kashmir, government jobs are the only reputed occupations and teaching is the most respectful profession. Also in this profession working hours remain flexible. (source: own fieldwork data)

Bisma Shora (Group-III caste) has done Master of Commerce (M. Com.) and is unemployed; she said:

I am looking for some job where I can get more than Rs. 8,000 per month. I have applied at few places but they are offering less than Rs 3,000 per month and that amount will be utilised only in transportation. Business sector in Kashmir is dominated by males and it is very difficult to think of business in Kashmir. I am very fond of mechanical work. At home, I often help my father in repairing mechanical devices but I cannot choose mechanical work as my career option. People will start teasing us if I join my father's workshop. Mechanical work is exclusively done by males. (source: own fieldwork data)

Employment choices of women of different castes are determined by the values and ethos which each of the castes possesses along with the overall religious and cultural values that they hold. Upper caste women are constrained to prefer specific types of employment in specific context and in the search of such employment they often remain unemployed. Patriarchy constraints even their choices. However, women coming from lower castes witness a strange situation: due to patriarchy, they are not allowed to join family occupation and the lack of 'caste capital' makes it difficult for them to find some decent occupation. The lack of provision of affirmative action (reservation) to these women further accelerates their marginalisation and deprivation.

\section{INCOME}

We observed that of the total Group-I males nobody falls within lower income group, 27 percent fall within middle income group, and almost 73 percent fall within higher income group. The corresponding percentage for females of Group-I is zero percent, 40 percent and 60 percent, respectively (Table 3). We find that the income of women of each caste group is lower as compared to their male counterparts. This reflects the marginalised position of women 
in Kashmir. Further, we observed that income of Group-III males is lower than the females of Group-I; of the total Group-III males, 5.5 percent fall within the lower income group, 56.7 percent fall within the middle income group and almost 37.8 percent fall within the higher income group. The income of Group-III women is the lowest among all caste categories, with almost 31 percent falling within the lower income group, around 55 percent falling within the middle income group, and only 15 percent (approximately) falling within the lower income group.

Table 3.

Gender and caste wise income status of respondents

\begin{tabular}{|c|c|c|c|c|c|c|c|c|}
\hline \multicolumn{9}{|c|}{ Annual Income ( in Rupees) } \\
\hline \multirow[t]{2}{*}{ Sex } & \multirow[t]{2}{*}{$\begin{array}{l}\text { Caste } \\
\text { Groups }\end{array}$} & \multicolumn{2}{|c|}{$\begin{array}{l}\text { Lower Income } \\
\text { Group }\end{array}$} & \multicolumn{2}{|c|}{$\begin{array}{l}\text { Middle Income } \\
\text { Group }\end{array}$} & \multicolumn{2}{|c|}{$\begin{array}{l}\text { Higher Income } \\
\text { Group }\end{array}$} & \multirow[t]{2}{*}{ Total } \\
\hline & & $\begin{array}{l}\text { Up-to } \\
24000\end{array}$ & $\begin{array}{c}24000- \\
48000\end{array}$ & $\begin{array}{l}48000- \\
120000\end{array}$ & $\begin{array}{l}120000- \\
300000\end{array}$ & $\begin{array}{c}300000- \\
600000 \\
\end{array}$ & $\begin{array}{l}\text { 600000- } \\
\text { Above }\end{array}$ & \\
\hline \multirow[t]{4}{*}{ Males } & Group-I & $0.0 \%$ & $0.0 \%$ & $7.7 \%$ & $19.2 \%$ & $38.5 \%$ & $34.6 \%$ & $100.0 \%$ \\
\hline & Group-II & $0.0 \%$ & $1.6 \%$ & $19.4 \%$ & $33.9 \%$ & $12.9 \%$ & $32.3 \%$ & $100.0 \%$ \\
\hline & Group-III & $1.0 \%$ & $4.5 \%$ & $29.6 \%$ & $27.1 \%$ & $18.9 \%$ & $18.9 \%$ & $100.0 \%$ \\
\hline & Total & $0.8 \%$ & $3.7 \%$ & $26.4 \%$ & $27.7 \%$ & $19.3 \%$ & $22.2 \%$ & $\begin{array}{l}100.0 \% \\
N=379\end{array}$ \\
\hline \multirow{4}{*}{ Females } & Group-I & $0.0 \%$ & $0.0 \%$ & $26.7 \%$ & $13.3 \%$ & $13.3 \%$ & $46.7 \%$ & $100.0 \%$ \\
\hline & Group-II & $8.0 \%$ & $4.0 \%$ & $24.0 \%$ & $32.0 \%$ & $12.0 \%$ & $20.0 \%$ & $100.0 \%$ \\
\hline & Group-III & $8.1 \%$ & $21.8 \%$ & $37.1 \%$ & $18.5 \%$ & $6.5 \%$ & $8.1 \%$ & $100.0 \%$ \\
\hline & Total & $7.3 \%$ & $17.1 \%$ & $34.1 \%$ & $20.1 \%$ & $7.9 \%$ & $13.4 \%$ & $\begin{array}{l}100.0 \% \\
N=164\end{array}$ \\
\hline \multirow[t]{4}{*}{ Total } & Group-I & $0.0 \%$ & $0.0 \%$ & $14.6 \%$ & $17.1 \%$ & $29.3 \%$ & $39.0 \%$ & $100.0 \%$ \\
\hline & Group-II & $2.3 \%$ & $2.3 \%$ & $20.7 \%$ & $33.3 \%$ & $12.6 \%$ & $28.7 \%$ & $100.0 \%$ \\
\hline & Group-III & $3.1 \%$ & $9.6 \%$ & $31.8 \%$ & $24.6 \%$ & $15.2 \%$ & $15.7 \%$ & $100.0 \%$ \\
\hline & Total & $2.8 \%$ & $7.7 \%$ & $28.7 \%$ & $25.4 \%$ & $15.8 \%$ & $19.5 \%$ & $\begin{array}{l}100.0 \% \\
N=543\end{array}$ \\
\hline
\end{tabular}

Source: own research

Further, the high proportion of low castes Group-III women possesses lower educational qualifications and those who have higher education typically have taken non-professional and non-technical courses. Substantial proportion of Group-III women is working in private sector which is often low paying. Further, in the absence of any caste capital they are left with almost no choice but either to join a low paid private job or to remain unemployed or in a state of disguised unemployment. Ufaq Dar is a 28-year-old female and has done Master of Commerce (M.Com.). Her father is self-employed (a washer man) and manages to earn up to Rs. 15,000/- per month. Ufaq Dar is from Group-III caste. Ufaq works as a teacher in one private play schools and her monthly income is Rs 4000/. On asking why she is working on such low income, she said: 
Journal of Education Culture and Society No. 2_2021

I have no other choice; I applied for a few government sector positions but all in vein as these positions are generally filled by those who have strong family connections. The school has transportation facility and I am able to save some money from my salary as I do not need to spend money on transportation. My father has fixed my marriage and I need some money for shopping as I cannot ask money my father for money every time. (source: own fieldwork data)

\section{CONCLUSION}

Our findings suggest that not all women experienced gender in the same way and that women are not a homogenous social category. Educational, occupational and income choices and actual attainments of men and women positioned in the labour market are getting impacted not only by their gender identities but also by their caste positions. In the absence of any 'caste capital' the lower caste (especially males) develop pessimistic attitude towards education and they believe that formal education is not going to give them any benefit. This orientation severely impacts women of their families and gets infused with the existing patriarchy, which triggers gender discrimination and biasness against lower caste women where domestic and care giving work is more prioritised than their education. In every patriarchal society, the popular and normal discourses hold women accountable for 'domestic and care giving work' and in the case of lower caste women this popular discourse stands as a barrier in getting formal education in general and professional higher education in particular. Hence, lower caste women become the victim of symbolic violence and remain excluded from the development and inclusion process. Although upper caste women are also supposed to fulfil the responsibilities of 'domestic and care giving work', their caste capital provides them with particular cultural capital which not only brings ideological change but also determines and impacts educational choices and academic success.

We find that educational profile of Group-III males is not remarkable and most of lower caste respondents have developed a pessimistic ideology towards education. Major role of education, as has been claimed by Bourdieu, is the social function of elimination. This involves the self-elimination of members of the lower strata from higher level of education (as appears in case of Nazir and Aafaq). Thus, education as an 'ideological state apparatus'(Althusser, 1971) creates such ideology among lower caste where they believe that formal education is not going to give them any benefits. They hold themselves accountable for their failure and get self-eliminated from the development system: in this way, upper caste exercises symbolic violence against lower caste. Lower caste section of population is underrepresented in service sector, especially government sector. The proportion is higher in self-employment but it is typically true for Group-III males who have left education and preferred to join their traditional family business or some other occupation. Lower levels of business sector is thus largely controlled and owned by males, especially Group-III males. Women are deliberately pushed out from their family busi- 
ness and are relegated to low paying private sectors, where salary often remains low. In a patriarchal society, woman sexuality is often used as a tool to keep her away from the business sector which is largely passed to the male progeny.

Thus, the employment position of Group-III women is woeful. Even those Group-III women who are highly qualified, are employed in low paying positions, command lower power, and many among them are unemployed. In the absence of any cultural capital, lower caste women fail to yield appropriate benefit from their formal education. In this regard, Bourdieu (2016) claims that the success of all school education depends fundamentally on the 'cultural capital' acquired initially from the family and lower caste largely lack any previous cultural capital and hence their previous education does not serve them much. Further, Bazaz (2020) finds that besides formal educational qualifications, there are other factors such as social capital, cultural capital, human capital, social capital, type and quality of employment and government policies which play important roles in connecting individual's educational attainment with employment. In the absence of these factors and due to various socio-economic and cultural impediments, most of these lower caste women remain deprived of descent jobs and many remain unemployed (Bazaz, 2020; Bazaz \& Akram, 2017). Although the rate of unemployment is higher across women of all caste groups, upper caste women often remain unemployed as a choice but lower castes women feel the compulsion to remain unemployed or accept very low paid jobs.

We found that within Group-III in Kashmir, there are specific castes like Naye, Ganae, Kalo, Nago, Dhobee, Darzee, Sofi, Shora, Najar, Dar, which are considered inferior and whose members are engaged in occupations which are considered defying, but such castes do not get any reservation in job or legal status of scheduled caste (SC), backward caste (BC) or other backward class $(\mathrm{OBC})$ as they get in other states or union territories of India. The socio-economic position of men and women of these caste groups is no different from the SC or OBC or BC in other parts of India. At present, Kashmir division of UT of Jammu and Kashmir is not availing much benefit of caste reservations and these lower castes are excluded from the overall development processes and inclusion; also, they do need any affirmative action. The situation is different for Group-I and Group-II respondents who resemble upper castes as they have enough accumulated capital (social and cultural capital) and generally join professional and technical courses and better employment positions.

To conclude, not all women face gender discrimination and inequality in the same way. In spite of the fact that across all caste groups it is largely male members of the family who undertake decisions for women, sometimes these decisions prove helpful in improving their socio-economic status, especially for upper caste women. It is typically lower caste women who face extreme form of gender discrimination. These women are the most excluded and marginalised section of the society who faces double discrimination due to patriarchy and due to their lower caste position which severely impacts their educational as well as employment choices. 


\section{REFERENCES}

[1] Acharya, S. S. (2018). Health equity in India: An examination through the lens of social exclusion. Journal of Social Inclusion Studies, 4(1), 104-130.

[2] Acker, J. (2006). Inequality regimes: gender, class and race in organisations. Gender and Society, 20(4), 441-464.

[3] Ahmed, I. (1978). Caste social stratification among Muslims in India. New Delhi: Manohar Publications.

[4] Ahmad, Z. (1962). Muslim caste in Uttar Pradesh. The Economic Weekly, 14(7), 325-336.

[5] Althusser, L. (1971). Ideology and ideological state Apparatuses. In L. Althusser (Ed.), Lenin and philosophy and other essays (pp. 127-186). New York: Monthly Review Press (Original work published 1970).

[6] Anderson, M. L., \& Tylor, H. R. (2008). Sociology: Understanding a diverse society. Belmond: Thomson Wadsworth.

[7] Bailey, F. G. (1957). Caste and the economic frontier: A village in highland Orissa. Manchester: Manchester University Press.

[8] Bazaz, R. Y. (2020). Education and employment generation: a sociological study of district Srinagar in Jammu and Kashmir. [Unpublished thesis]. Aligarh Muslim University, Aligarh, India.

[9] Bazaz, R. Y., \& Akram, M. (2017). Education and unemployment in Jammu and Kashmir: a study on embedding employability into the educational curriculum. The Eastern Anthropologists, 70(3-4), 285-300.

[10] Bazaz, R. Y., \& Akram. M. (2020). Background characteristics of the individuals attaining higher education in India: A sociological study of Srinagar city. Journal of Education, Culture and Society, 11(2), 252-266.

[11] Bhattacharya, R. K. (1978). The concept and ideology of caste among the Muslims of rural West Bengal. In I. Ahmed (Ed.), Caste social stratification among Muslims in India (pp. 269-298). New Delhi: Manohar Publications.

[12] Bougle, C. (1958). The essence and reality of caste system, Contribution to Indian Sociology, 11 (1), 7-30.

[13] Bourdieu, P. (2016). The forms of capital. In A. R. Sadovnik, \& R. W. Coughlan (Ed.), Sociology of education: A critical reader (pp. 83-95). London: Routledge.

[14] Census of India, (2011). Office of the Registrar General \& Census Commissioner, India Ministry of Human Affairs, Government of India.

[15] Chand, S. V. (1994) Caste, gender and subjectivity in contemporary India, Women: A Cultural Review, 5(1), 25-33.

[16] Dabla, B. A. (2009). Ethnicity in Kashmir: Studies in culture, religion, economy and social structure. Srinagar: Jay Kay Books.

[17] Dabla, B. A. (2012). Directory of caste in India in Kashmir. Srinagar: Jay Kay books.

[18] Gruber, J. E. (1998). The impact of male work environments and organisational policies on women's experiences of sexual harassment. Gender \& Society, 12(3), 301-320.

[19] Gupta, N. (2019). Intersectionality of gender and caste in academic performance: quantitative study of an elite Indian engineering institute. Gender, Technology and Development, 23(2), 165-186.

[20] Hirway, I. (2015). Inclusive growth under a neoliberal policy framework: Some critical questions. In P. Balakrishnan (Ed.), Economic growth and its distribution in India: Essays from Economic and Political Weekly (pp. 337-355). New Delhi: Orient Black Swan.

[21] Holmes, M. (2007). What is gender? Sociological approaches. London: Sage.

[22] Jamil, G, (2018). Muslim women speak of dreams and shackles. New Delhi: Sage Publications and Yoda Press.

[23] Lawrence, R. (1891). The valley of Kashmir. London: Oxford University Press.

[24] Mines, M. (1978). Caste stratification among the Muslim Tamils in Tamil Nadu, South India. In I. Ahmed (Ed.), Caste social stratification among Muslims in India (pp. 159-169). New Delhi: Manohar Publications.

[25] Mondal, S. R. (2003). Social structure, OBCs and Muslims. Economic and Political Weekly, 38(46), 4892-4897. 
[26] Myrdal, G., \& King. (1972). Asian drama: An inquiry into the poverty of nations. Harmond sworth: Allen Lane/The Penguin Press.

[27] Oakley, A. (1974). Housewife. London: Allen Lane

[28] Pathania, G. J., \& Tierney, W. G. (2018). An ethnography of caste and class at an Indian university: creating capital. Tertiary Education and Management, 24(3), 221-231.

[29] Sen, A. (1999). Development as freedom. Oxford: OUP.

[30] Sinha, K.S. (2003). JEK anthropological survey of India. New Delhi: Monohara Publication.

[31] Smith, V. (2013). Sociology of work: An encyclopedia. Thousand Oaks, CA: Sage Publication.

[32] Sudarshan, R. M. (2016). Enabling equality: girls's education, social norms and community interventions. In A. K Singh (Ed.), Education and empowerment in India (pp. 141-154). New Delhi: Routledge.

[33] Velaskar, P. (1990). Unequal schooling as a factor in the reproduction of inequality in India. Sociological Bulletin, 39(1-2), 131-145.

[34] Velaskar, P. (2016). Theorising the interaction of caste, class and gender: a feminist sociological approach. Contributions to Indian Sociology, 50(3), 389-414.

[35] Wolkowitz, C. (2006). Bodies at work. London: Sage.

[36] Zainuddin, S. (2003). Islam, social stratification and empowerment of Muslims OBCs. Economic and Political Weekly, 38(56), 4898-4901. 